\title{
Conceptual Frameworks of Individual Work Performance
}

\author{
A Systematic Review
}

\author{
Linda Koopmans, MSc, Claire M. Bernaards, PhD, Vincent H. Hildebrandt, PhD, Wilmar B. Schaufeli, PhD, \\ Henrica C.W. de Vet, PhD, and Allard J. van der Beek, PhD
}

\begin{abstract}
Objective: Individual work performance is differently conceptualized and operationalized in different disciplines. The aim of the current review was twofold: (1) identifying conceptual frameworks of individual work performance and (2) integrating these to reach a heuristic conceptual framework. Methods: A systematic review was conducted in medical, psychological, and management databases. Studies were selected independently by two researchers and included when they presented a conceptual framework of individual work performance. Results: A total of 17 generic frameworks (applying across occupations) and 18 job-specific frameworks (applying to specific occupations) were identified. Dimensions frequently used to describe individual work performance were task performance, contextual performance, counterproductive work behavior, and adaptive performance. Conclusion: On the basis of the literature, a heuristic conceptual framework of individual work performance was proposed. This framework can serve as a theoretical basis for future research and practice.
\end{abstract}

I ndividual work performance is an issue that has not only grasped companies all over the world but also fueled a great deal of research in fields of management, occupational health, and work and organizational psychology. ${ }^{1-4}$ Numerous studies on individual work performance have been conducted. However, different approaches of studying individual work performance circulate in today's literature. Whereas the field of management has primarily occupied itself with how one can make an employee as productive as possible, the field of occupational health has focused on how to prevent productivity loss due to a certain disease or health impairment. ${ }^{5,6}$ Work and organizational psychologists, on the other hand, have an interest in the influence of determinants, such as work engagement, satisfaction, and personality, on individual work performance..$^{7-9}$

In all of the research fields mentioned earlier, individual work performance is a relevant outcome measure of studies in the occupational setting. However, despite its importance, no comprehensive conceptual framework of individual work performance exists. A solid theoretical framework is a prerequisite for optimal measurement of the construct. ${ }^{4}$ It has typically been assumed that what constitutes individual work performance differs from job to job. As a result, countless measures of work performance have been used. ${ }^{10}$ So far, the assessment of individual work performance has primarily focused either on objective measures of work productivity (such

From the Body@Work (Drs Koopmans, Bernaards, Hildebrandt, de Vet, and van der Beek), Research Center for Physical Activity, Work and Health, TNO VU University Medical Center, Amsterdam, the Netherlands; Expertise Center Life Style (Drs Koopmans, Bernaards, and Hildebrandt), TNO, Leiden, the Netherlands; Department of Social and Organisational Psychology (Dr Schaufeli), Utrecht University, Utrecht, the Netherlands; Department of Epidemiology and Biostatistics (Dr de Vet), EMGO + Institute for Health and Care Research, VU University Medical Center, Amsterdam, the Netherlands; and Department of Public and Occupational Health (Koopmans and van der Beek), EMGO + Institute for Health and Care Research, VU University Medical Center, Amsterdam, the Netherlands.

Address correspondence to: Linda Koopmans, MSc, TNO, PO Box 2215, 2301 CE, Leiden, the Netherlands; E-mail: linda.koopmans@tno.nl.

Copyright (C) 2011 by American College of Occupational and Environmental Medicine

DOI: 10.1097/JOM.0b013e318226a763 as the number of days absent, counts of specified acts, or output maintained in organizational records) or on subjective judgments of quantity and quality of work from the employee him- or herself, peers, or supervisors. ${ }^{11,12}$ While these methods may provide valuable information, it can be argued that none of them capture the complexity and full range of behaviors that constitute an employee's performance at work. ${ }^{4,13}$

This raises the question of what exactly constitutes individual work performance. Work performance is an abstract, latent construct that cannot be pointed to or measured directly. ${ }^{14}$ It is made up of multiple components or dimensions. These dimensions, in turn, are made up of indicators that can be measured directly. To conceptualize and operationalize individual work performance, we should explicate the construct domain of work performance and identify its dimensions and indicators. ${ }^{4,14,15}$ Whereas the dimensions may generalize across jobs, the exact indicators can differ between jobs. ${ }^{14}$ In the field of psychology, the conceptualization of work performance has received relatively much attention. A widely endorsed definition of work performance is that of Campbell: "behaviors or actions that are relevant to the goals of the organization."4 Three notions accompany this definition: (1) work performance should be defined in terms of behavior rather than results, (2) work performance includes only those behaviors that are relevant to the organization's goals, and (3) work performance is multidimensional. As distinguishing between behavior and results can be difficult, others have included results in their definition of work performance. For example, Viswesvaran and Ones ${ }^{11}$ defined work performance as "scalable actions, behavior and outcomes that employees engage in or bring about that are linked with and contribute to organizational goals.'

Work performance should be distinguished from work productivity, two concepts that often seem to be used interchangeably in the literature. Work productivity is defined as input divided by output. ${ }^{12}$ Thus, work productivity is a narrower concept than work performance. It is also important to distinguish between causal variables and indicators of work performance. Causal variables determine or predict one's level of work performance, whereas indicators are reflections of work performance. ${ }^{16}$ For example, job satisfaction is considered a determinant of work performance, ${ }^{8}$ whereas work quality is an indicator of work performance. ${ }^{4}$ The current review focuses only on indicators of work performance and not on its determinants.

Thus, until now, no clear consensus exists on what exactly constitutes individual work performance. The aim of the current review was twofold: (1) identifying conceptual frameworks of individual work performance and (2) integrating the conceptual frameworks to reach a heuristic conceptual framework of individual work performance.

\section{METHODS}

\section{Search Strategy}

A systematic search was conducted to identify frameworks describing the construct of individual work performance. The primary searches were conducted April/May 2010 in two medical databases (PubMed and Embase.com), one psychological (PsycINFO), and 
one management (ABI Inform) database. The search was restricted to literature written in English or Dutch. No restrictions were placed on the year of publication or publication type. All search strategies were developed with the aid of experienced search specialists. Search strategies are presented in Table 1. Additional studies were identified by scanning the reference lists of suitable studies and in personal collections.

\section{Study Selection}

The first reviewer determined the eligibility of studies on the basis of title and abstract. Studies that presented a framework describing the construct of individual work performance were included. Exclusion criteria were as follows: (1) not on work performance, (2) not at the individual level, or (3) not on a framework describing the construct of individual work performance. A second reviewer independently determined the eligibility of the studies that the first reviewer found suitable or doubtful. In addition, the second reviewer determined the eligibility of 100 random studies per database, thus, a total of 400 random studies, to get an indication of whether the first

\section{TABLE 1. Search Strategies}

\begin{tabular}{|c|c|}
\hline Database & Search Strategy \\
\hline PubMed & 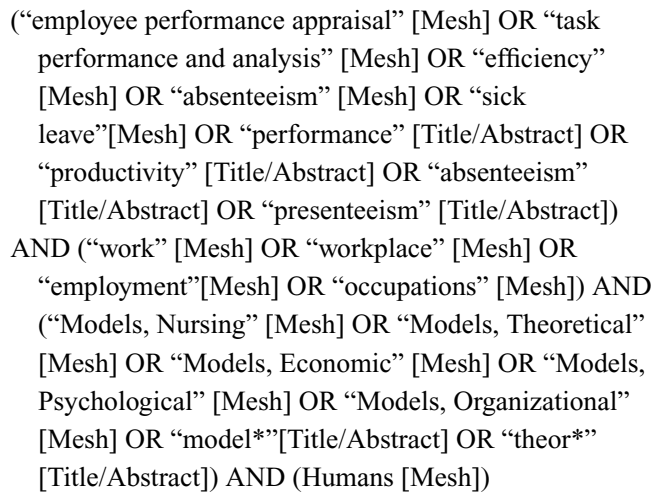 \\
\hline Embase.com & $\begin{array}{l}\text { ('job performance':cl,ab,ti OR 'task performance':cl,ab,ti } \\
\text { OR 'productivity':cl,ab,ti OR 'absenteeism':cl,ab,ti OR } \\
\text { 'medical leave':cl,ab,ti OR 'presenteeism':ab,ti) } \\
\text { AND ('work':cl,ab,ti OR 'occupation':cl,ab,ti OR } \\
\text { 'employee':cl,ab,ti OR 'job':cl,ab,ti) } \\
\text { AND ('model':cl,ab,ti OR 'theory':cl,ab,ti OR 'conceptual } \\
\text { framework':cl,ab,ti) AND [humans]/lim }\end{array}$ \\
\hline PsycINFO & $\begin{array}{l}\text { ((“job performance” OR “employee productivity” OR } \\
\text { “occupational success” OR “employee absenteeism” OR } \\
\text { "presenteeism” OR “sick leave”) } \\
\text { AND (“models" OR “theories” OR "model” OR } \\
\text { “theory”)).ti,ab,id. }\end{array}$ \\
\hline ABI Inform & $\begin{array}{l}\text { LSU (job performance) OR LSU (performance appraisal) } \\
\text { OR LSU (organizational behavior) OR LSU (employee } \\
\text { attitude) OR LSU (performance management) OR LSU } \\
\text { (performance evaluation) } \\
\text { AND TI OR ABS (“job performance" OR "performance } \\
\text { appraisal” OR “employee performance" OR “work } \\
\text { productivity" OR "absenteeism" OR "presenteeism”) } \\
\text { AND (LSU (models) OR LSU (theory) OR TI (“model”) } \\
\text { OR TI (“theory”) OR ABS (“model”) OR ABS } \\
\text { (“theory”)) AND LSU (individual) OR ABS } \\
\text { ("individual”) OR TI (“individual”) }\end{array}$ \\
\hline
\end{tabular}

reviewer had missed relevant studies. Differences in judgment were resolved through a consensus procedure. Finally, the first reviewer determined eligibility of all suitable or doubtful studies based on full text.

\section{RESULTS}

\section{Study Selection}

The searches in PubMed, Embase.com, PsycINFO, and ABI Inform resulted in 760, 553, 1328, and 478 hits, respectively. From this total of 3119 hits, 252 duplicates were removed, resulting in 2867 studies to be screened. Of these, 107 studies were found eligible on the basis of title and abstract. Consensus rates between the 2 reviewers were $75 \%$ for PubMed, $79 \%$ for Embase.com, $84 \%$ for PsycInfo, and $68 \%$ for ABI Inform. Differences in judgment were resolved through a consensus procedure, resulting in full agreement. The full papers of the 107 eligible studies were screened. These included 65 articles, 11 book chapters, and 31 dissertations. Of these 107 results, 24 dissertations could not be retrieved in full text. They could, therefore, not be judged on their eligibility and were excluded from the review. Out of the 83 remaining studies, 49 were included in the review, on the basis of full text. Seven of the included studies were identified in PubMed, 1 in Embase.com, 33 in PsycInfo, and 8 in ABI Inform. With nine articles found in additional searches of reference lists and of TNO and VU University medical center literature databases, a total of 58 studies were included in this review. Forty of these were articles, 12 were book chapters, and 6 were dissertations. Figure 1 presents a flowchart of the study selection process. In short, 921 of the studies were excluded because they did not report on work performance, 119 because they did not report on work performance at the individual level, and 1754 because they did not present a framework describing the construct of individual work performance.

\section{General Description of the Studies}

Fifty-eight studies were identified that presented a conceptual framework of individual work performance. In 35 of the 58 studies, an original conceptual framework was presented. The remaining 23 studies did not present a new conceptual framework but referred to

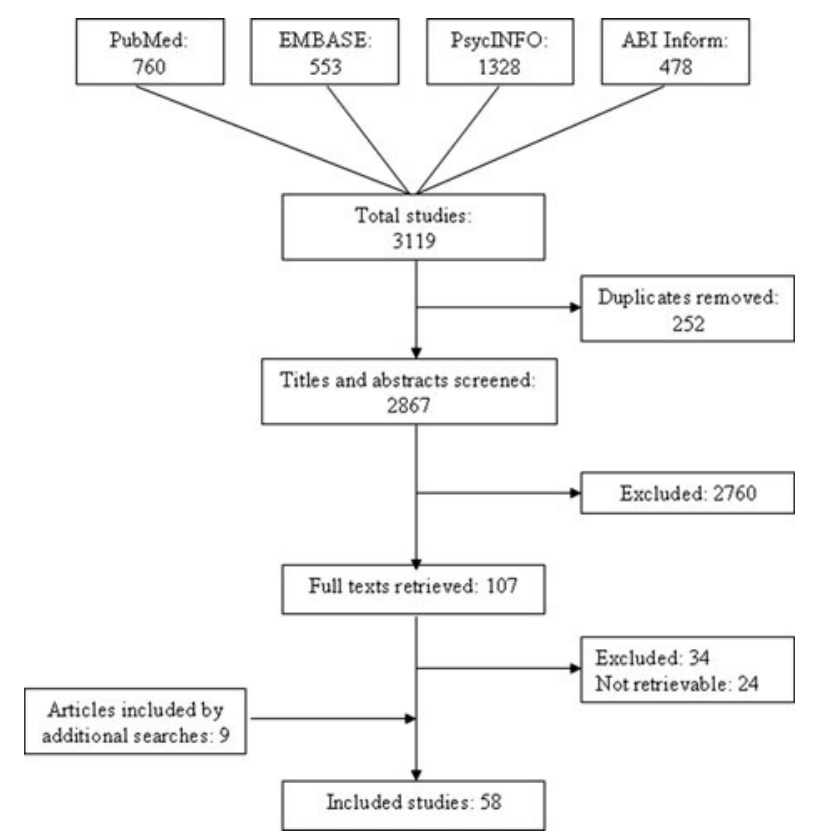

FIGURE 1. Flowchart of study selection process. 
one of the other original conceptual frameworks. Seventeen generic frameworks (ie, applying to work performance across all occupations) and 18 job-specific frameworks (ie, applying to work performance in a specific occupation) were identified. Table 2 presents an overview of identified conceptual frameworks. A description of some often-presented frameworks is given later.

Murphy ${ }^{17}$ and Campbell ${ }^{4}$ were among the first to define the domain of individual work performance by specifying the major dimensions of generic work performance. ${ }^{4,17}$ According to Murphy, the work performance domain could be modeled using the following four dimensions: (1) task behaviors, (2) interpersonal behaviors (communicating and cooperating with others), (3) downtime behaviors (work-avoidance behaviors), and (4) destructive/hazardous behaviors (behaviors that lead to a clear risk of productivity losses, damage, or other setbacks). Campbell's work performance framework proposed eight work performance dimensions: (1) job-specific task proficiency, (2) non-job-specific task proficiency, (3) written and oral communications, (4) demonstrating effort, (5) maintaining personal discipline, (6) facilitating peer and team performance, (7) supervision, and (8) management and administration. According to Campbell, these eight dimensions are sufficient to describe the latent structure of performance at a general level. How ever, he also noted that the eight factors can have different patterns of subdimensions, and their content and salience can vary across jobs.

On the basis of the conceptual grouping of 486 measures of work performance found in the literature, Viswesvaran ${ }^{21}$ developed 10 dimensions of individual work performance. Besides a general factor of overall job performance, he distinguished the dimensions of productivity, quality of work, job knowledge, communication competence, effort, leadership, administrative competence, interpersonal competence, and compliance with/acceptance of authority.

Borman and Motowidlo ${ }^{35}$ argued that the entire work performance domain could be encompassed by the comprehensive dimensions of task performance and contextual performance. ${ }^{35}$ They describe task performance as behaviors that directly or indirectly contribute to the organization's technical core, and contextual performance as behaviors that support the organizational, social, and psychological environment in which the technical core must function. Examples of contextual activities are volunteering, persisting, helping, cooperating, and following rules. ${ }^{35}$ Task activities usually vary between different jobs, whereas contextual activities are common to many or all jobs.

In the early 2000s, Viswesvaran and Ones ${ }^{11}$ and Rotundo and Sackett ${ }^{18}$ conducted two narrative reviews on frameworks of individual work performance. Both reviews concluded that three broad dimensions of work performance could be distinguished: task performance, organizational citizenship behavior, and counterproductive work behavior. The term organizational citizenship behavior was first introduced by Organ ${ }^{67}$ and is currently defined as individual behavior that contributes to the maintenance and enhancement of the social and psychological context that supports task performance. ${ }^{68}$ Although originally there were some definitional differences between organizational citizenship behavior and contextual performance, Organ's definition of organizational citizenship behavior has evolved to greatly overlap with Borman and Motowidlo's definition of contextual performance. ${ }^{68}$ In the current review, the term contextual performance will be used to refer to behaviors that support the organizational, social, or psychological environment in which the technical core functions. The third dimension, counterproductive work behavior, was defined as behavior that harms the well-being of the organization. ${ }^{18}$ It includes behaviors such as absenteeism, off-task behavior, theft, and substance abuse.

Frameworks developed for specific jobs were mainly targeted at professions in the army, managers, or sales and service industry. In 1990, Campbell et al ${ }^{69}$ developed a framework in which work performance in the army was described by five dimensions: (1) core technical proficiency, (2) general soldiering proficiency, (3) effort and leadership, (4) personal discipline, and (5) physical fitness and military bearing. The last referred to the degree to which individuals stay in good physical condition, maintain appropriate military appearance, and carry or conduct oneself appropriately. Campbell's more comprehensive eight-dimensional framework ${ }^{4}$ is largely based on this framework. Borman and Brush ${ }^{60}$ developed a framework, on the basis of critical incidents analysis, in which managerial work performance was described by (1) technical activities and mechanisms of management, (2) interpersonal dealings and communication, (3) leadership and supervision, and (4) useful personal behavior and skills (eg, persistence, handling crises and stress, organizational commitment). This framework was developed independent of Borman and Motowidlo's two-dimensional framework. ${ }^{35}$ Maxham et $\mathrm{al}^{36}$ described performance of retail employees as (1) in-role performance, (2) extra-role performance toward customers, and (3) extra-role performance toward the organization.

Generic frameworks used more broad dimensions to describe work performance, whereas job-specific frameworks used more narrow dimensions to describe elements of work performance. Despite these different levels of specificity, similarities were observed between dimensions of individual work performance described in the frameworks. On the basis of conceptual grouping of individual work performance dimensions found in the literature, three broad dimensions could be distinguished: task performance, contextual performance, and counterproductive work behavior. Finally, some frameworks described dimensions that they did not classify in one of these three categories, such as proactive, creative, and adaptive performance. Table 2 shows the classification of dimensions from each framework. The original dimensions of the frameworks were classified in the scheme of Table 2 on the basis of the definitions of the dimensions as provided by the developers of the framework. When the original dimensions were not defined, they were classified on the basis of the authors' own insight.

\section{Task Performance}

Almost all frameworks mentioned task performance as an important dimension of individual work performance. Task performance can be defined as the proficiency (ie, competency) with which one performs central job tasks. ${ }^{4}$ Other labels sometimes used for task performance are job-specific task proficiency, ${ }^{13,22,57,59}$ technical proficiency, ${ }^{23,58,69}$ or in-role performance. ${ }^{36,50} \mathrm{It}$ includes, for example, work quantity, work quality, and job knowledge. ${ }^{4}$

In Murphy's ${ }^{17}$ framework, the first dimension, labeled task behaviors, could be considered task performance. Campbell ${ }^{4}$ himself stated that his first two dimensions, job-specific task proficiency (core job tasks) and non-job-specific task proficiency (tasks not specific to a given job, but expected of all employees), represent task performance. ${ }^{11}$ Viswesvaran's ${ }^{21}$ first three dimensions, productivity, quality, and job knowledge, could be considered task performance. Later developed individual work performance frameworks all included one dimension to describe task performance. ${ }^{11,13,18,24,35,45,50,54}$ The only exception was Renn and Fedor's framework, in which task performance was split into work quantity and quality. ${ }^{47}$

Of course, what constitutes core job tasks can differ from job to job. In contrast to generic frameworks, job-specific frameworks often used multiple, specific dimensions to describe task performance. For example, Arvey and Mussio ${ }^{55}$ described task performance of clerical workers, using the dimensions of working accurately, showing concern for time and detail and planning. Jiambalvo ${ }^{56}$ described task performance for public accountants as understanding, planning, and revising work. Engelbrecht and Fischer ${ }^{61}$ divided task performance for managers into action orientation (eg, getting things done, decisiveness), task structuring (eg, leadership, planning), and probing, synthesis, and judgment (problem resolution). Furthermore, Tett et $\mathrm{al}^{62}$ divided task performance for managers into traditional 
TABLE 2. Overview of Identified Conceptual Frameworks of Individual Work Performance and Classification of Their Dimensions

\begin{tabular}{|c|c|c|c|c|}
\hline \multirow[b]{2}{*}{ Generic framework } & \multicolumn{4}{|c|}{ Dimension } \\
\hline & Task Performance & Contextual Performance & $\begin{array}{c}\text { Counterproductive Work } \\
\text { Behavior }\end{array}$ & Other \\
\hline $\begin{array}{l}\text { Murphy }{ }^{17} \\
\text { Also presented in references } \\
\quad 14,18,19,20\end{array}$ & Task behaviors & Interpersonal behaviors & $\begin{array}{l}\text { Downtime behaviors } \\
\text { Destructive/hazardous } \\
\text { behaviors }\end{array}$ & \\
\hline $\begin{array}{l}\text { Campbell }^{4} \\
\text { Also presented in references } \\
\quad 10,11,13,14,18,20-34\end{array}$ & $\begin{array}{l}\text { Job-specific task } \\
\text { proficiency } \\
\text { Non-job-specific task } \\
\text { proficiency }\end{array}$ & $\begin{array}{l}\text { Written and oral communications } \\
\text { Demonstrating effort } \\
\text { Maintaining personal discipline } \\
\text { Facilitating peer and team } \\
\quad \text { performance } \\
\text { Supervision and leadership } \\
\text { Management and administration }\end{array}$ & & \\
\hline $\begin{array}{l}\text { Borman and Motowidlo }{ }^{35} \\
\text { Also presented in references } \\
\quad 7,10,11,13,14,18,20,21,24,25,27- \\
\quad 30,32,33,36-42\end{array}$ & Task performance & Contextual performance & & \\
\hline $\begin{array}{l}\text { Viswesvaran }^{21} \\
\text { Also presented in references } \\
\quad 10,11,14,20,30,34,39\end{array}$ & $\begin{array}{l}\text { Productivity } \\
\text { Quality } \\
\text { Job knowledge }\end{array}$ & $\begin{array}{l}\text { Communication competence } \\
\text { Effort } \\
\text { Leadership } \\
\text { Administrative competence } \\
\text { Interpersonal competence } \\
\text { Compliance with and acceptance of } \\
\text { authority }\end{array}$ & & $\begin{array}{l}\text { Overall work } \\
\text { performance }\end{array}$ \\
\hline Hunt $^{43}$ & & Adherence to rules & Off-task behavior & \\
\hline $\begin{array}{c}\text { Also presented in references } \\
11,14,18,20,24,34\end{array}$ & & $\begin{array}{l}\text { Industriousness } \\
\text { Thoroughness } \\
\text { Schedule flexibility } \\
\text { Attendance }\end{array}$ & $\begin{array}{l}\text { Unruliness } \\
\text { Theft } \\
\text { Drug misuse }\end{array}$ & \\
\hline Allworth and Hesketh ${ }^{44}$ & Task performance & Contextual performance & & $\begin{array}{l}\text { Adaptive } \\
\text { performance }\end{array}$ \\
\hline $\begin{array}{l}\text { Viswesvaran and Ones }{ }^{11} \\
\text { Also presented in reference } 39\end{array}$ & Task performance & Organizational citizenship behavior & Counterproductive behavior & \\
\hline Michel $^{24}$ & Task performance & $\begin{array}{l}\text { Interpersonal performance } \\
\text { Civic performance }\end{array}$ & & \\
\hline $\begin{array}{l}\text { Pulakos et } \mathrm{al}^{45} \\
\text { Also presented in references } \\
\quad 13,20,32,46\end{array}$ & Task performance & Contextual performance & & $\begin{array}{l}\text { Adaptive } \\
\text { performance }\end{array}$ \\
\hline Renn and Fedor ${ }^{47}$ & $\begin{array}{l}\text { Work quantity } \\
\text { Work quality }\end{array}$ & & & \\
\hline $\begin{array}{l}\text { Rotundo and Sackett }{ }^{18} \\
\text { Also presented in references } \\
\quad 15,48,49\end{array}$ & Task performance & Organizational citizenship behavior & Counterproductive behavior & \\
\hline Bakker et al ${ }^{50}$ & In-role performance & Extra-role performance & & \\
\hline Burton et $\mathrm{al}^{51}$ & & & $\begin{array}{l}\text { Absenteeism } \\
\text { Presenteeism }\end{array}$ & \\
\hline $\begin{array}{l}\text { Griffin et a }{ }^{13} \\
\text { Also presented in reference } 15 \\
\text { Allen }^{52}\end{array}$ & Task proficiency & & $\begin{array}{l}\text { Absenteeism } \\
\text { Presenteeism }\end{array}$ & $\begin{array}{l}\text { Adaptability } \\
\text { Proactivity }\end{array}$ \\
\hline
\end{tabular}


TABLE 2. continued

\begin{tabular}{|c|c|c|c|c|}
\hline \multirow[b]{2}{*}{ Generic framework } & \multicolumn{4}{|c|}{ Dimension } \\
\hline & Task Performance & Contextual Performance & $\begin{array}{c}\text { Counterproductive Work } \\
\text { Behavior }\end{array}$ & Other \\
\hline Escorpizo $^{53}$ & & & $\begin{array}{l}\text { Absenteeism } \\
\text { Presenteeism }\end{array}$ & \\
\hline Fluegge $^{54}$ & Task performance & Organizational citizenship behavior & & $\begin{array}{l}\text { Creative } \\
\text { performance }\end{array}$ \\
\hline Arvey and Mussio ${ }^{55}$ & $\begin{array}{l}\text { Working accurately } \\
\text { Showing concern for } \\
\text { time }\end{array}$ & $\begin{array}{l}\text { Cooperating and extra time } \\
\text { Dealing with others in organization }\end{array}$ & & \\
\hline & Detail and planning & $\begin{array}{l}\text { Dealing with public } \\
\text { Showing responsibility and initiative }\end{array}$ & & \\
\hline Jiambalvo $^{56}$ & $\begin{array}{l}\text { Understanding } \\
\text { Planning } \\
\text { Revising }\end{array}$ & $\begin{array}{l}\text { Promoting } \\
\text { Providing training } \\
\text { Recognizing problems } \\
\text { Suggesting solutions } \\
\text { Reviewing work } \\
\text { Cooperation } \\
\text { Respect } \\
\text { Special competence }\end{array}$ & & \\
\hline C. Campbell et $\mathrm{al}^{57}$ & Job-specific proficiency & Non-job-specific proficiency & & \\
\hline J. Campbell et al ${ }^{69}$ & Core technical & General soldiering proficiency & & \\
\hline Also presented in reference 58 & proficiency & $\begin{array}{l}\text { Effort and leadership } \\
\text { Personal discipline } \\
\text { Physical fitness and military bearing }\end{array}$ & & \\
\hline Lance et $\mathrm{al}^{23}$ & Technical proficiency & Interpersonal proficiency & & \\
\hline Rollins and Fruge ${ }^{59}$ & Task proficiency & $\begin{array}{l}\text { Action } \\
\text { Teamwork } \\
\text { Creativity } \\
\text { Communication } \\
\text { Decision making } \\
\text { Leadership } \\
\text { Accountability } \\
\text { Adaptability } \\
\text { Development }\end{array}$ & & \\
\hline $\begin{array}{l}\text { Borman and Brush }{ }^{60} \\
\text { Also presented in references } \\
\quad 18,20,30\end{array}$ & $\begin{array}{l}\text { Technical activities and } \\
\text { mechanics of } \\
\text { management }\end{array}$ & $\begin{array}{l}\text { Interpersonal dealings and } \\
\text { communication } \\
\text { Leadership and supervision } \\
\text { Useful personal behavior and skills }\end{array}$ & & \\
\hline Engelbrecht and Fischer ${ }^{61}$ & $\begin{array}{l}\text { Action orientation } \\
\text { Task structuring } \\
\text { Probing, synthesis and } \\
\quad \text { judgment }\end{array}$ & $\begin{array}{l}\text { Empathy } \\
\text { Development } \\
\text { Managing information }\end{array}$ & & \\
\hline Tett et $\mathrm{al}^{62}$ & $\begin{array}{l}\text { Traditional functions } \\
\text { Occupational acumen } \\
\text { and concerns }\end{array}$ & $\begin{array}{l}\text { Task orientation } \\
\text { Person orientation } \\
\text { Dependability } \\
\text { Open mindedness } \\
\text { Emotional control } \\
\text { Communication } \\
\text { Developing self and others }\end{array}$ & & \\
\hline
\end{tabular}


TABLE 2. continued

\begin{tabular}{|c|c|c|c|c|}
\hline \multirow[b]{2}{*}{ Generic framework } & \multicolumn{4}{|c|}{ Dimension } \\
\hline & Task Performance & Contextual Performance & $\begin{array}{c}\text { Counterproductive Work } \\
\text { Behavior }\end{array}$ & Other \\
\hline Van Dyne et al ${ }^{31}$ & Sales performance & Creativity & & \\
\hline Hedge et al ${ }^{63}$ & Resource stewardship & $\begin{array}{l}\text { Coaching and mentoring } \\
\text { Professionalism and integrity } \\
\text { Communication skills } \\
\text { Leading change } \\
\text { Leading people } \\
\text { Organizational savvy } \\
\text { Personal and professional } \\
\text { development }\end{array}$ & & \\
\hline Chan $^{64}$ & & $\begin{array}{l}\text { Communication skills } \\
\text { Interpersonal skills } \\
\text { Customer service } \\
\text { Analytical skills }\end{array}$ & & \\
\hline Sinclair and Tucker ${ }^{25}$ & Task performance & Contextual performance & Counterproductive behavior & $\begin{array}{l}\text { Adaptive } \\
\text { performance }\end{array}$ \\
\hline Greenslade and Jimmison ${ }^{41}$ & Task performance & Contextual performance & & \\
\hline Wisecarver et al ${ }^{22}$ & $\begin{array}{l}\text { Job-specific task } \\
\text { proficiency } \\
\text { Interpersonal } \\
\text { job-specific task } \\
\text { proficiency }\end{array}$ & $\begin{array}{l}\text { Non-job-specific task proficiency } \\
\text { Management } \\
\text { Peer-team interaction } \\
\text { Discipline } \\
\text { Effort }\end{array}$ & & \\
\hline Luo et $\mathrm{al}^{65}$ & $\begin{array}{l}\text { Military training } \\
\text { Task accomplishment } \\
\text { Work capability }\end{array}$ & $\begin{array}{l}\text { Helping others } \\
\text { Love of learning } \\
\text { Promoting organizational benefit } \\
\text { Self-discipline }\end{array}$ & & \\
\hline Maxham et al ${ }^{36}$ & In-role performance & $\begin{array}{l}\text { Extra-role performance toward } \\
\text { customers } \\
\text { Extra-role performance toward } \\
\text { organization }\end{array}$ & & \\
\hline Mael et al ${ }^{66}$ & $\begin{array}{l}\text { Providing clinical } \\
\text { services }\end{array}$ & Employee citizenship behavior & & \\
\hline & Clinical support & Managerial behavior & & \\
\hline
\end{tabular}

functions (eg, decision making, planning) and occupational acumen and concerns (eg, job knowledge, concern for quantity and quality).

\section{Contextual Performance}

Although task performance has been the traditional focus of research, researchers have come to believe that individual work performance is more than meeting prescribed work goals. ${ }^{11,35}$ In both generic and job-specific frameworks, one or more dimensions of contextual performance have been included. Contextual performance can be defined as individual behaviors that support the organizational, social, and psychological environment in which the technical core must function. ${ }^{35}$ Several labels exist for this dimension, such as non-job-specific task proficiency, ${ }^{22,57}$ extra-role performance, ${ }^{36,50}$ organizational citizenship behavior, ${ }^{11,18,54}$ or interpersonal relations. ${ }^{17}$ All concepts, however, refer to behaviors that go beyond the formally prescribed work goals, such as taking on extra tasks, showing initiative, or coaching newcomers on the job.

Seven of the generic frameworks used one broad dimension to describe contextual performance. Four generic frameworks used multiple dimensions to describe contextual performance. For example, in Campbell's framework, ${ }^{4}$ six of the eight dimensions (written and oral communications, demonstrating effort, maintaining personal discipline, facilitating peer and team performance, supervision and leadership, and management and administration) could be regarded contextual performance. Also, six of Viswesvaran's dimensions $^{21}$ (communication competence, effort, leadership, administrative competence, interpersonal competence, and compliance with/acceptance of authority) could be regarded as contextual performance.

Job-specific frameworks often used multiple, more specific dimensions to describe contextual performance. For example, Arvey and Mussio ${ }^{55}$ described contextual performance of clerical workers, using the dimensions of cooperating and taking on extra load, showing responsibility and initiative, dealing with others in the organization, and dealing with public. Campbell et al ${ }^{69}$ distinguished general soldiering proficiency, effort, leadership, personal discipline, and physical fitness and military bearing as dimensions of work perfor-

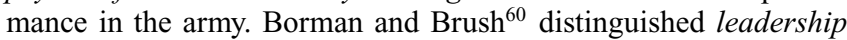
and supervision, interpersonal dealings and communication, and useful personal behavior and skills as dimensions of managerial work performance. Altogether, dimensions frequently named under contextual performance are communication, effort, discipline, 
interpersonal behavior, and leading and developing others. Less frequently named dimensions are planning, solving problems, administration, and showing responsibility.

\section{Counterproductive Work Behavior}

Attention for counterproductive work behavior, defined as behavior that harms the well-being of the organization, has increased in recent years. ${ }^{18}$ It includes behaviors such as absenteeism, being late for work, engaging in off-task behavior, theft, and substance abuse.

Almost half of the generic individual work performance frameworks incorporated one or more dimensions of counterproductive work behavior. Murphy ${ }^{17}$ used the dimensions of destructive/hazardous behaviors (behaviors leading to a clear risk of productivity losses, damage, or other setbacks) and downtime behaviors (work-avoidance behaviors) to describe behaviors that harm the organization. Hunt's framework ${ }^{43}$ incorporated the four dimensions of off-task behavior, unruliness, theft, and drug misuse. Viswesvaran and Ones, ${ }^{11}$ as well as Rotundo and Sackett, ${ }^{18}$ concluded in their reviews that counterproductive work behavior should be distinguished as a third broad dimension of individual work performance (in addition to task performance and organizational citizenship behavior). Finally, some individual work performance frameworks that focus only on counterproductive work behavior were identified. Burton et al, ${ }^{51}$ Allen, ${ }^{52}$ and Escorpizo ${ }^{53}$ approached the study of work performance from an occupational health perspective and divided the work performance domain into absenteeism (not attending work) and presenteeism (attending work while ill). Both absenteeism and presenteeism could be regarded as counterproductive work behaviors, as they are behaviors that harm the well-being of the organization.

Sinclair and Tucker's framework ${ }^{25}$ was the only job-specific framework to incorporate counterproductive work behavior as a separate dimension of individual work performance.

\section{Other Dimensions}

To examine the impact of fun at work on work performance, Fluegge ${ }^{54}$ divided the domain of individual work performance into task performance, organizational citizenship behavior, and creative performance. Creative performance was defined as behavioral manifestations of creativity, which refer to the generation of ideas, procedures, and products that are both novel and useful.

Allworth and Hesketh, ${ }^{44}$ Pulakos et $\mathrm{al},{ }^{45}$ and Griffin et al ${ }^{13}$ focused on the growing interdependency and uncertainty of work systems and the corresponding change in the nature of individual work performance. All three argued that adaptive performance should be a separate dimension of individual work performance. Adaptive performance is defined as the extent to which an individual adapts to changes in a work system or work roles. ${ }^{13}$ It includes, for example, solving problems creatively, dealing with uncertain or unpredictable work situations, learning new tasks, technologies, and procedures, and adapting to other individuals, cultures, or physical surroundings. Griffin et $\mathrm{al}^{13}$ further argued for task proactivity as a separate dimension of work performance. Individual task proactivity reflected the extent to which individuals engage in self-starting, future-oriented behavior to change their work situations, their work roles, or themselves.

Sinclair and Tucker's job-specific framework ${ }^{25}$ also regarded adaptive performance as a separate dimension of individual work performance, in addition to task performance, contextual performance, and counterproductive work behavior. In several other frameworks, adaptive performance was not included as a separate dimension, but rather as a part of contextual performance. For example, Hunt's ${ }^{43}$ dimension of schedule flexibility, Rollins and Fruge's ${ }^{59}$ dimension of adaptability, and Hedge et al's ${ }^{63}$ dimension of leading change all reflected an employee's ability to adapt to new job conditions or requirements.

\section{Heuristic Conceptual Framework of Individual Work Performance}

The second aim of the current review was to integrate existing conceptual frameworks in order to formulate a heuristic conceptual framework of individual work performance. We propose a heuristic framework, presented in Figure 2, which may serve as a guide toward understanding the construct of individual work performance. At the highest level appears the latent, general factor of individual work performance. Research has shown the existence of a general factor, which accounts for substantial variation in job performance ratings. ${ }^{39}$ At the second level, four dimensions of individual work performance are located. At the third level, the individual measures corresponding to each dimension are located. The importance of these dimensions, and the exact indicators associated with each dimension, may differ depending on the context involved.

The first dimension, task performance, refers to the proficiency with which central job tasks are performed. ${ }^{4}$ The second dimension, contextual performance, refers to behaviors that support the organizational, social, and psychological environment in which the technical core must function. ${ }^{35}$ As a third dimension, adaptive performance is included in the heuristic framework. Three reasons support the inclusion of adaptive performance, referring to an employee's ability to adapt to changes in a work system or work roles, ${ }^{13}$ as a separate dimension. First, because of the technological changes occurring in today's society, being able to adapt to a changing work environment is increasingly important. Second, conceptually, adaptive performance does not fit neatly under task performance, contextual performance, or counterproductive work behavior. Whereas contextual performance comprises behaviors that positively influence the work environment, adaptive performance comprises behaviors in reaction to the changing work environment. Third, empirical support for adaptive performance as a separate dimension was provided by Allworth and Hesketh. ${ }^{44}$ They found that adaptive performance had differential predictors than task or contextual performance. The fourth dimension, counterproductive work behavior, refers to behavior that harms the well-being of the organization. ${ }^{18}$

Other dimensions that have been suggested as separate dimensions are proactive and creative performance. ${ }^{13,54}$ Although proactive and creative performance can be a part of task performance in some jobs, we considered these part of contextual performance, as both contribute to a positive organizational, social, and psychological work environment. Each of the four dimensions is latent, meaning that they cannot be measured directly. ${ }^{14}$ Example indicators of each dimension that were gathered from the identified frameworks are presented in the square boxes in Figure 2.

\section{Relation Between Dimensions}

Not only are the separate dimensions related to the general factor of work performance, they are also related to each other. ${ }^{39}$ Interesting is the question of how the separate dimensions interrelate. Task performance is distinct, albeit strongly positively related, with contextual performance. ${ }^{34,70}$ Both types of behavior independently contribute to overall performance, but through different means. ${ }^{29,35}$ Because of the changing nature of today's work, the distinction between task and contextual performance may become more blurred. ${ }^{30}$ Increasingly, contextual behaviors are implicitly or explicitly required as task behaviors. Also, some behaviors can be seen as task behaviors in some jobs, while they may be seen as contextual behaviors in other jobs. Findings on the relation between task performance and counterproductive work behavior are inconclusive and have been found to be either moderately or strongly negative. ${ }^{71}$ The inconclusive findings could be caused by differences in definition and measurement of task performance. When task performance is defined as what a person generally "will do," it is more strongly related to counterproductive work behavior than when task 


\section{Construct}

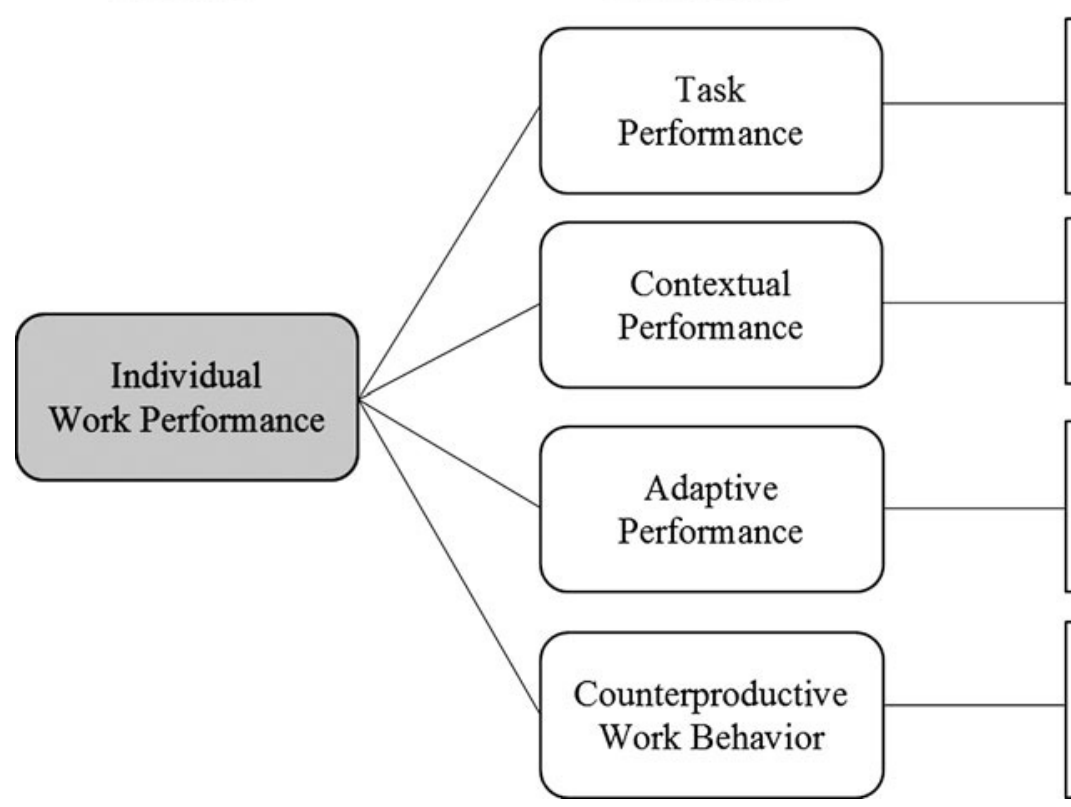

\section{Indicators}

Completing job tasks, work quantity, work quality, job skills, job knowledge, keeping knowledge up-to-date, working accurately and neatly, planning and organizing, administration, decision making, solving problems, oral and written communication, monitoring and controlling resources.

Extra tasks, effort, initiative, enthusiasm, attention to duty, resourcefulness, industriousness, persistence, motivation, dedication, proactivity, creativity, cooperating with and helping others, politeness, effective communication, interpersonal relations. organizational commitment.

Generating new, innovative ideas, adjusting goals and plans to situation, learning new tasks and technologies, being flexible and open-minded to others, understanding other groups or cultures, showing resilience, remaining calm, analyzing quickly, acting appropriately.

Off-task behavior, too many or longer breaks, presenteeism, absenteeism, complaining, tardiness, doing tasks incorrectly, accidents, insulting or gossiping about coworkers, fighting or arguing with coworkers, disregard of safety, misusing privileges, aggression, theft, substance use.

FIGURE 2. Heuristic framework of individual work performance.

performance is defined as what a personal maximally "can do." This is because typical work performance is usually assessed over a longer time period, in which counterproductive work behaviors are more likely to occur. In addition, typical task performance is often less closely monitored than maximal task performance, making counterproductive work behaviors more likely to occur. ${ }^{71}$

Intuitively, one would expect a negative relation between contextual behavior and counterproductive work behavior. Someone who often engages in behavior that helps the organization will not often engage in behavior that harms the organization and vice versa. Although a strong negative correlation has been found previously, ${ }^{71}$ meta-analysis demonstrated that the true relation between contextual performance and counterproductive work behavior is modestly negative. ${ }^{72}$ Three methodological artifacts may have caused the strong negative relation between contextual performance and counterproductive work behavior in previous research. First, the relation was found to be more strongly negative when the behaviors were rated by supervisors rather than by the employees themselves. This is because supervisors often cannot accurately observe an employee's counterproductive work behavior and make their judgment on the basis of general impressions of the employee. Second, the relation was more strongly negative when contextual behavior inventories included dysfunctional behaviors (eg, "not adhering to organizational rules") or when counterproductive work behavior inventories included functional behaviors (eg, "adhering to organizational rules"). Dalal ${ }^{72}$ termed these overlapping items antithetical items. Third, asking respondents to indicate the extent to which they agreed or disagreed with statements about their behavior resulted in a stronger negative relation between contextual performance and counterproductive work behavior than when they were asked to indicate the frequency of their behavior. In conclusion, the relation between contextual performance and counterproductive work behavior is modestly negative. Thus, employees who engage in helping behavior tend not to engage in harming behavior (or vice versa), but both types of behavior can occur together, at least to some extent. ${ }^{73}$

Although Pulakos et $\mathrm{al}^{74}$ stated that adaptive performance does not occur completely independent of task and contextual performance, to our knowledge, no research has been published that examines the relation between adaptive performance and the other individual work performance dimensions. However, as adaptive performance is regarded behavior that positively influences individual work performance, one can expect a positive relation with task and contextual performance, and a negative relation with counterproductive work behavior.

\section{DISCUSSION}

The aim of the current review was to identify conceptual frameworks of individual work performance from different fields in order to formulate a heuristic conceptual framework. In total, 17 generic frameworks were identified that addressed individual work performance across occupations. Eighteen job-specific frameworks were identified that addressed work performance of either professionals in the army and managers or employees in the service and sales industry. Although job-specific frameworks often used multiple, more specific dimensions than generic frameworks to describe the construct of individual work performance, clear similarities were observed in the dimensions of these frameworks. A heuristic framework of individual work performance was proposed in which individual work performance consists of four dimensions, namely, task performance, contextual performance, adaptive performance, and counterproductive work behavior. These four types of behavior can be considered to capture the full range of behaviors that constitute individual work performance in virtually any job. The importance of the four dimensions, and their exact indicators, may however differ on the basis of the specific context.

In accordance with two previous narrative reviews, ${ }^{11,18}$ the heuristic framework incorporates task performance, contextual performance, and counterproductive work behavior as important dimensions of individual work performance. However, the current review presents an updated conceptual framework in which adaptive performance is added to the domain of individual work performance. Although some frameworks have included adaptive performance as a part of contextual performance, we presented societal, conceptual, and empirical reasons for distinguishing adaptive performance as a separate dimension. 
Surprisingly, none of the identified frameworks included all four dimensions proposed in the heuristic framework, except for the recent Sinclair and Tucker framework for work performance of soldiers. ${ }^{25}$ While most of the identified individual work performance frameworks circulate in the field of management or in the field of work and organizational psychology, they have been almost absent in the field of occupational health. In this field, only three studies were identified, describing individual work performance as existing of absenteeism and presenteeism. ${ }^{51-53}$ It is hoped that the present review will facilitate information exchange between the different areas of research.

\section{Strengths and Limitations}

The present review has several strengths. First of all, this is the first study to examine the construct of individual work performance from different research fields, namely occupational health, psychology, and management. We concluded that there are considerable similarities between the different fields. Second, this is the first study to conduct a comprehensive, systematic literature search in order to identify frameworks describing the construct of individual work performance. Both earlier reviews ${ }^{11,18}$ were narrative reviews describing a limited amount of conceptual frameworks. Third, both generic and job-specific frameworks were included in the present review. Overall, the present review provides a strong basis for the proposed heuristic framework.

The present review has some limitations as well. We aimed to describe all individual work performance frameworks as comprehensively as possible. However, it cannot be ruled out that some frameworks were missed. Although no restrictions in year or type of publication were made, only Dutch and English literature was searched. Furthermore, all literature was searched for the search terms in their title or abstract. This may have excluded studies that did present a conceptual framework of individual work performance but did not mention this in their title or abstract. We tried to minimize these limitations by searching four databases, using broad search terms and checking reference lists from identified studies. Unfortunately, 24 dissertations that appeared eligible on the basis of title and abstract had to be excluded from this review, because, after thorough searches, we were unable to retrieve them in full text.

The original dimensions of the identified frameworks were classified into the heuristic framework on the basis of the definitions of the dimensions as provided by the developers of the framework. However, depending on the specific context, the importance and the place of the original dimensions may differ. For example, in some jobs, adaptive performance may not be important at all and could therefore be excluded from the heuristic framework. In some jobs, communication competence may be an aspect of contextual performance, while in other jobs it may be an aspect of task performance. Thus, the dimensions, and subsequently the indicators used for its measurement, may differ depending on the context. In addition, the heuristic framework, or any job performance framework for that matter, is influenced by the Zeitgeist. Contextual performance (and its variants) has gained currency in the 1960s, whereas adaptive performance has gained currency only in recent years. In one or two decades, other dimensions may become important (eg, environmental sustainability) and some existing dimensions may become oblivious.

\section{Recommendations for Future Research}

The heuristic framework of individual work performance that is presented in the current review can serve as a guide for future research and practice. An important next step is to identify existing measures or to develop a new measurement instrument that can adequately measure the individual work performance dimensions proposed in the heuristic framework. This will involve determining the exact indicators of each dimension more comprehensively.
Empirical data gathered with the measurement instrument provide information on whether the four-dimensional structure of the proposed framework is supported, whether the indicators belong to the expected dimension, and on the exact relation between the different dimensions.

Furthermore, future research is needed to examine whether the proposed framework is generalizable across all types of jobs. Considering the similarity in dimensions observed between generic and job-specific frameworks, we believe that the broad dimensions of the proposed framework will likely generalize across all job types. The importance of the dimensions, and their exact indicators, may however be job-specific. An important next step for future research is therefore to determine whether or not the four dimensions proposed in the heuristic framework are generic and whether the indicators per dimensions are job-specific or generic. Future research is also needed to determine whether adding adaptive performance as a separate dimension of individual work performance is justified. In this sense, the proposed framework may be considered a theory-driven "working" framework that can be adapted on the basis of future empirical research.

\section{Practical Use of the Framework}

An important use of the heuristic framework is in shaping the design of workplace interventions and assessing the effects of that intervention on individual work performance. Think, for example, of intervention studies that target managerial style or employee lifestyle and health to increase an individual's work performance. Furthermore, the heuristic framework can be used in companies for employee selection, evaluation, training, and development.

Future research may expand the heuristic framework to include causes and consequences of individual work performance. Individual work performance is inextricably linked to team and organizational performance, although the exact nature of this relationship is yet unknown. A final extension would be to expand the heuristic framework to the team and organizational levels, and possibly, to relate it to company costs.

\section{CONCLUSION}

The dimensions of task performance, contextual performance, adaptive performance, and counterproductive work behavior comprise the heuristic framework of individual work performance. Future research will have to determine empirical support for and practical relevance of this framework. It is hoped that this review provides a step toward reaching consensus on the conceptualization and operationalization of individual work performance. A better understanding of this construct will improve theory, research, and practice in all fields occupied with individual work performance.

\section{ACKNOWLEDGMENT}

This studywas funded by Body@Work Research Center. Competing interests: none.

\section{REFERENCES}

1. Waldman DA. The contributions of total quality management to a theory of work performance. Acad Manag Rev. 1994;19:510-536.

2. Evans CJ. Health and work productivity assessment: state of the art or state of flux? J Occup Environ Med. 2004;46:S3-S11.

3. Lerner D, Mosher Henke R. What does research tell us about depression, job performance, and work productivity? J Occup Environ Med. 2008;50:401410 .

4. Campbell JP. Modeling the performance prediction problem in industrial and organizational psychology. In: Dunnette MD, Hough LM, eds. Handbook of Industrial and Organizational Psychology. Palo Alto, CA: Consulting Psychologists Press; 1990:687-732.

5. Beaton D, Bombardier C, Escorpizo R, et al. Measuring worker productivity: frameworks and measures. J Rheumatol. 2009;36:2100-2109. 
6. Schultz AB, Chen CY, Edington DW. The cost and impact of health conditions on presenteeism to employers. Pharmacoeconomics. 2009;27: $365-378$.

7. Halbeslebe JRB, Wheeler AR, Buckley MR. Clarifying the relationship between organizational commitment and job performance: extending the conservation of resources model. In: Kiefer KH, ed. Applied Psychology Research Trends. Hauppauge, NY: Nova Science Publishers; 2008:35-58.

8. Judge TA, Bono JE, Thoreson CJ, Patton GK. The job satisfaction-job performance relationship: a qualitative and quantitative review. Psychol Bull. 2001;127:376-407.

9. Barrick MR, Mount MK, Judge TA. Personality and performance at the beginning of the new millennium: what do we know and where do we go next? Int J Select Assess. 2001;9:9-30.

10. Tubre T, Arthur WJ, Bennett WJ. General models of job performance: theory and practice. In: Bennett W Jr, Lance CE, Woehr DJ, eds. Performance Measurement: Current Perspectives and Future Challenges. Mahwah, NJ: Lawrence Erlbaum Associates Publishers; 2006:175-203.

11. Viswesvaran C, Ones DS. Perspectives on models of job performance. Int $J$ Select Assessm. 2000;8:216-226.

12. Kemppila S, Lonnqvist A. Subjective productivity measurement. $J$ Am Acad Business. 2003;2:531-537.

13. Griffin MA, Neal A, Parker SK. A new model of work role performance: positive behavior in uncertain and interdependent contexts. Acad Manag J. 2007;50:327-347.

14. Viswesvaran C. Assessment of individual job performance: a review of the past century and a look ahead. In: Anderson N, Ones DS, Sinangil HK, Viswesvaran C, eds. Handbook of Industrial, Work and Organizational Psychology. Vol 1: Personnel Psychology. Thousand Oaks, CA: Sage Publications Ltd; 2002:110-126.

15. Fay D, Sonnentag S. A look back to move ahead: new directions for research on proactive performance and other discretionary work behaviours. Appl Psychol An Int Rev. 2010;59:1-20.

16. Fayers PM, Hand DJ. Causal variables, indicator variables and measurement scales: an example from quality of life. J Royal Statist Soc. 2002;165 233-261.

17. Murphy KR. Dimensions of job performance. In: Dillon RF, Pellegrino JW, eds. Testing: Theoretical and Applied Perspectives. New York: Praeger; 1989:218-247.

18. Rotundo M, Sackett PR. The relative importance of task, citizenship, and counterproductive performance to global ratings of performance: a policycapturing approach. J Appl Psychol. 2002;87:66-80.

19. Murphy KR. Job performance and productivity. In: Murphy KR, Saal FE, eds Psychology in Organizations: Integrating Science and Practice. Hillsdale, $\mathrm{NJ}$, England: Lawrence Erlbaum Associates Inc; 1990:157-176.

20. Levine PJ. Substandard job performance: development of a model and the examination of poor organizational performers. Dissertation Abstr Int Sect B Sci Eng. 2007;67:5454.

21. Viswesvaran C. Modeling Job Performance: Is There a General Factor? [PhD dissertation]. Iowa City: The University of Iowa; 1993.

22. Wisecarver MM, Carpenter TD, Kilcullen RN. Capturing interpersonal performance in a latent performance model. Milit Psychol. 2007;19:83-101.

23. Lance CE, Teachout MS, Donnelly TM. Specification of the criterion construct space: an application of hierarchical confirmatory factor analysis. $J \mathrm{Appl}$ Psychol. 1992;77:437-452.

24. Michel RP. A model of entry-level job performance. Dissertation Abstr Int Sect B Sci Eng. 2000;61(6-B):3313.

25. Sinclair RR, Tucker JS. Stress-CARE: an integrated model of individual differences in soldier performance under stress. In: Britt TW, Castro CA, Adler AB, eds. Military Life: The Psychology of Serving in Peace and Combat (Vol. 1): Military Performance. Westport, CT: Praeger Security International; 2006:202-231.

26. Campbell JP. Alternative models of job performance and their implications for selection and classification. In: Rumsey MG, Walker CB, Harris JH, eds. Personnel Selection and Classification. Hillsdale, NJ, and England: Lawrence Erlbaum Associates Inc; 1994:33-51.

27. Conway JM. Additional construct validity evidence for the task/contextual performance distinction. Hum Perform. 1996;9:309-329.

28. Borman WC, Hanson MA, Hedge JW. Personnel selection. Annu Rev Psychol. 1997;48:299-337.

29. Motowidlo SJ, Borman WC, Schmit MJ. A theory of individual differences in task and contextual performance. Hum Perform. 1997;10:71-83.

30. Arvey RD, Murphy KR. Performance evaluation in work settings. Annu Rev Psychol. 1998;49:141-168.
31. Van Dyne L, Jehn KA, Cummings A. Differential effects of strain on two forms of work performance: individual employee sales and creativity. J Organ Behav. 2002;23:57.

32. Borman WC, Hedge JW, Ferstl KL, Kaufman JD, Farmer WL, Bearden RM. Current directions and issues in personnel selection and classification. In: Martocchio JJ, Ferris GR, eds. Research in Personnel and Human Resources Management. Oxford, England: Elsevier Science Ltd; 2003:297-355.

33. Surface EA. An integration of the training evaluation and job performance modeling literatures: Confirming BE KNOW DO with United States army special forces training data. Dissertation Abstr Int Sect B Sci Eng. 2004;65:471.

34. Hoffman BJ, Blair CA, Meriac JP, Woehr DJ. Expanding the criterion domain? A quantitative review of the OCB literature. $J$ Appl Psychol. 2007;92:555566.

35. Borman WC, Motowidlo SJ. Expanding the criterion domain to include elements of contextual performance. In: Schmitt N, Borman WC, eds. Personnel Selection in Organizations. San Francisco, CA: Jossey Bass; 1993:71-98.

36. Maxham JGI, Netemeyer RG, Lichtenstein DR. The retail value chain: linking employee perceptions to employee performance, customer evaluations, and store performance. Market Sci. 2008;27:147-167.

37. Van Scotter JR, Motowidlo SJ. Interpersonal facilitation and job dedication as separate facets of contextual performance. J Appl Psychol. 1996;81: 525 .

38. Borman WC, Penner LA, Allen TD, Motowidlo SJ. Personality predictors of citizenship performance. Int J Select Assess. 2001;9:52-69.

39. Viswesvaran C, Schmidt FL, Ones DS. Is there a general factor in ratings of job performance? A meta-analytic framework for disentangling substantive and error influences. $J$ Appl Psychol. 2005;90:108-131.

40. Ellington JK. Systematic sources of variance in supervisory job performance ratings: a multilevel analysis of between-rater and between-context variance. Dissertation Abstr Int Sect B Sci Eng. 2007;67:7413.

41. Greenslade JH, Jimmieson NL. Distinguishing between task and contextual performance for nurses: development of a job performance scale. $J A d v$ Nurs. 2007;58(6):602-611.

42. Wang H, Law K, Chen Z. Leader-member exchange, employee performance, and work outcomes: an empirical study in the Chinese context. Int J Hum Res Manag. 2008;19:1809.

43. Hunt ST. Generic work behavior: an investigation into the dimensions of entry-level, hourly job performance. Pers Psychol. 1996;49:51-83.

44. Allworth E, Hesketh B. Construct-oriented biodata: capturing change-related and contextually relevant future performance. Int J Select Assess. 1999;7:97111.

45. Pulakos ED, Arad S, Donovan MA, Plamondon KE. Adaptability in the workplace: development of a taxonomy of adaptive performance. $J$ Appl Psychol. 2000;85:612-624

46. Pulakos ED, Schmitt N, Dorsey DW, Arad S, Hedge JW, Borman WC. Predicting adaptive performance: further tests of a model of adaptability. Hum Perform. 2002;15:299-324.

47. Renn RW, Fedor DB. Development and field test of a feedback seeking, selfefficacy, and goal setting model of work performance. J Manag. 2001;27: 563.

48. Colquitt JA, Scott BA, LePine JA. Trust, trustworthiness, and trust propensity: a meta-analytic test of their unique relationships with risk taking and job performance. J Appl Psychol. 2007;92:909-927.

49. Mount MK, Oh IS, Burns M. Incremental validity of perceptual speed and accuracy over general mental ability. Pers Psychol. 2008;61: $113-139$.

50. Bakker AB, Demerouti E, Verbeke W. Using the job demands-resources model to predict burnout and performance. Hum Resour Manag. 2004;43:83104.

51. Burton WN, Pransky G, Conti DJ, Chen CY, Edington DW. The association of medical conditions and presenteeism. J Occup Environ Med. 2004;46(suppl):S38-S45.

52. Allen $\mathrm{H}$. Using routinely collected data to augment the management of health and productivity loss. J Occup Environ Med. 2008;50:615-632.

53. Escorpizo R. Understanding work productivity and its application to work-related musculoskeletal disorders. Int $J$ Indust Ergon. 2008;38:291-297.

54. Fluegge ER. Who put the fun in functional? Fun at work and its effects on job performance. Dissertation Abstr Int Sect A Hum Soc Sci. 2009;69:2781.

55. Arvey RD, Mussio SJ. A test of expectancy theory in a field setting using female clerical employees. J Vocat Behav. 1973;3:421-432.

56. Jiambalvo J. Performance evaluation and directed job effort: model development and analysis in a CPA firm setting. J Account Res. 1979;17:436. 
57. Campbell CH, Ford P, Rumsey MG, et al. Development of multiple job performance measures in a representative sample of jobs. Pers Psychol. 1990;43:277-300.

58. Campbell JP, Hanson MA, Oppler SH. Modeling performance in a population of jobs. In: Campbell JP, Knapp DJ, eds. Exploring the Limits in Personnel Selection and Classification. Mahwah, NJ: Lawrence Erlbaum Associates Publishers; 2001:307-333.

59. Rollins T, Fruge M. Performance dimensions: competencies with a twist. Training. 1992;29:47-51.

60. Borman WC, Brush DH. More progress toward a taxonomy of managerial performance requirements. Hum Perform. 1993;6:1-21.

61. Engelbrecht AS, Fischer AH. The managerial performance implications of a developmental assessment center process. Hum Relat. 1995;48:387-404.

62. Tett RP, Guterman HA, Bleier A, Murphy PJ. Development and content validation of a "hyperdimensional" taxonomy of managerial competence. Hum Perform. 2000;13:205-251.

63. Hedge JW, Borman WC, Bruskiewicz KT, Bourne MJ. The development of an integrated performance category system for supervisory jobs in the US Navy. Milit Psychol. 2004;16:231-243.

64. Chan DC. Core competencies and performance management in Canadian public libraries. Library Manag. 2006;27:144.

65. Luo Z, Shi K, Li W, Miao D. Construct of job performance: evidence from Chinese military soldiers. Asian J Soc Psychol. 2008;11:222-231.
66. Mael FA, O'Shea PG, Smith MA, et al. Development of a model and measure of process-oriented quality of care for substance abuse treatment. J Behav Health Serv Res. 2010;37:4-24.

67. Organ DW. Organizational Citizenship Behavior: The Good Soldier Syndrome. Lexington, MA: Lexington Books; 1988.

68. LePine JA, Erez A, Johnson DE. The nature and dimensionality of organizational citizenship behavior: a critical review and meta-analysis. $J$ Appl Psychol. 2002;87:52-65.

69. Campbell JP, McHenry JJ, Wise LL. Modeling job performance in a population of jobs. Pers Psychol. 1990;43:313-333.

70. Conway JM. Distinguishing contextual performance from task performance for managerial jobs. J Appl Psychol. 1999;84:3-13.

71. Sackett PR. The structure of counterproductive work behaviors: dimensionality and relationships with facets of job performance. Int J Select Assess. 2002;10:5-11.

72. Dalal RS. A meta-analysis of the relationship between organizational citizenship behavior and counterproductive work behavior. J Appl Psychol. 2005;90:1241-1255.

73. Spector PE, Fox S. Theorizing about the deviant citizen: an attributional explanation of the interplay of organizational citizenship and counterproductive work behavior. Hum Res Manag Rev. 2010;20:132-143.

74. Pulakos ED, Dorsey DW, White SS. Adaptability in the workplace: selecting an adaptive workforce. Adv Hum Perform Cogn Eng Res. 2006;6:41-71. 